\title{
Penampilan Karakter Hortikultura Beberapa Varietas Tomat Hibrida di Rumah Kaca Dataran Rendah
}

\section{Performance of Horticultural Characteristics of Several Hybrid Tomato Varieties in the Lowland Greenhouse}

\author{
Ady Daryanto*, Muhammad Ridha Alfarabi Istiqlal, Ummu Kalsum, dan Ratih Kurniasih \\ Program Studi Agroteknologi, Fakultas Teknologi Industri, Universitas Gunadarma \\ Jl. Margonda Raya No. 100 Pondok Cina, Depok, Jawa Barat 16424, Indonesia
}

Diterima 27 April 2020/Disetujui 6 Agustus 2020

\begin{abstract}
Urban farming activities are needed to support food security, nutrition, and vitamins for families in urban areas. Information on the characteristics of tomato varieties for urban farming in the greenhouse is still limited. The objective of this research was to evaluate the horticultural characteristics of several hybrid tomato varieties grown in the lowland greenhouse. The experiment was carried out using a randomized complete block design (RCBD) on 5 hybrid tomato varieties with 3 replications at Gunadarma University's greenhouse, Depok City, West Java, from October 2018 to January 2019. There were significant differences for all quantitative characters among 5 varieties. Tymoti and Tantyna varieties showed good performance at lowland and had good size for vegetable tomato type. Agatha and Ultima varieties showed a fruit size decreasing to $40 \%$ in lowland greenhouse. Rewako variety was not suitable for lowland because of the highest flower dropping and lowest fruit setting. Plant growth, young fruit color, and fruit shape in the longitudinal section are important identification keys of tomato variety.
\end{abstract}

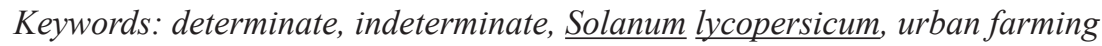

\section{ABSTRAK}

Kegiatan urban farming diperlukan untuk mendukung ketahanan pangan, nutrisi serta vitamin bagi keluarga di wilayah urban. Informasi karakteristik varietas tomat untuk penanaman urban farming di dalam greenhouse masih terbatas. Penelitian ini bertujuan mengevaluasi karakteristik hortikultura beberapa varietas tomat hibrida yang ditanam di dalam greenhouse dataran rendah. Percobaan dilaksanakan dengan rancangan kelompok lengkap teracak (RKLT) terhadap 5 varietas tomat hibrida dengan 3 ulangan. Percobaan dilakukan di greenhouse percobaan Universitas Gunadarma di Wilayah Kota Depok, Jawa Barat, pada bulan Oktober 2018 hingga Januari 2019. Hasil penelitian menunjukkan bahwa kelima varietas yang diuji memiliki perbedaan pada semua karakter kuantitatif. Varietas Tymoti dan Tantyna menunjukkan penampilan yang baik di wilayah dataran rendah serta memiliki ukuran buah yang sesuai untuk tomat sayur. Varietas Agatha dan Ultima mengalami penurunan ukuran buah hingga 40\% di greenhouse dataran rendah. Varietas Rewako tidak sesuai untuk penanaman di wilayah dataran rendah karena gugur bunga yang sangat tinggi dan pembentukan buah yang sangat rendah. Karakter kualitatif yang mencirikan masing-masing varietas adalah tipe tumbuh, warna pundak buah muda, bentuk buah, dan bentuk ujung buah.

Kata kunci: determinate, indeterminate, Solanum lycopersicum, urban farming

\section{PENDAHULUAN}

Tanaman tomat (Solanum lycopersicum L.) merupakan salah satu komoditas tanaman sayuran dari famili Solanaceae dengan jumlah kromosom $2 \mathrm{n}=2 \mathrm{x}=24$ (Geethanjali et al., 2010; Priya et al., 2019) yang diproduksi serta dikonsumsi secara luas di dunia (Guan et al., 2018). Tomat dapat

\footnotetext{
* Penulis untuk korespondensi. e-mail: adydaryanto@yahoo.com
}

dikonsumsi secara langsung sebagai sayuran ataupun diolah menjadi saus tomat dalam industri (Shamshiri et al., 2018). Kebutuhan buah tomat semakin meningkat sejalan dengan peningkatan jumlah penduduk, peningkatan daya beli dan dinamika iklim global. Data PUSDATIN (2017) menunjukkan bahwa konsumsi tomat nasional pada periode 2017-2021 diproyeksikan naik dengan pertumbuhan ratarata $5.32 \%$ per tahun.

Salah satu upaya untuk membangun ketahanan pangan di wilayah perkotaan adalah melalui pemanfaatkan ruang 
dan pekarangan dengan kegiatan urban farming (Ashari et al., 2012). Masyarakat kota mulai menyadari pentingnya kegiatan urban farming akan tetapi memiliki keterbatasan informasi mengenai karakteristik varietas-varietas yang sesuai untuk ditanam di wilayah perkotaan. Varietas yang beredar, termasuk tomat, belum spesifik dirakit untuk keperluan urban farming. Beberapa perusahaan benih baru sekedar membungkus ulang varietas komersilnya ke dalam bentuk kemasan kecil, small poach.

Varietas tomat yang telah dilepas oleh Menteri Pertanian sampai tahun 2020 sebanyak 204 varietas dan sebagian besar varietas tersebut dirakit dalam bentuk varietas hibrida oleh perusahaan benih swasta nasional dan multinasional (Direktorat Perbenihan Hortikultura, 2020). Konstruksi genetik varietas hibrida adalah homogen heterozigot dengan potensi heterosis (Shivaprasad et al., 2012) sehingga varietas hibrida memerlukan kondisi lingkungan yang optimum untuk mencapai potensi hasil yang optimal (Carrillo-Rodríguez et al., 2019; Sujitno dan Dianawati, 2017).

Budidaya di dalam greenhouse dapat memberikan kualitas hasil produksi yang tinggi serta sesuai untuk wilayah dengan keterbatasan lahan dan sumber daya (Shamshiri et al., 2018) seperti wilayah urban. Di Negara maju produksi tomat dilakukan di dalam greenhouse untuk mendapatkan hasil yang optimal (Yuan et al., 2016; Bojaca et al., 2014). Akan tetapi budidaya tanaman di dalam greenhouse memiliki tantangan peningkatan suhu yang dapat menyebabkan cekaman panas pada tanaman (Boulard et al., 2011) sehingga diperlukan varietas yang sesuai.

Penelitian ini menggunakan varietas tomat hibrida bertipe determinate dan indeterminate. Varietas determinate berhabitus pendek, cepat berbunga dan ukuran buah sedang. Varietas indeterminate memiliki habitus tinggi, ukuran buah besar dan waktu panen relative lebih lama dibandingkan varietas determinate (Sujitno dan Dianawati, 2017; Sutjahjo et al., 2015). Penelitian ini bertujuan untuk mengevaluasi penampilan hortikultura beberapa varietas tomat hibrida yang sesuai dengan kondisi greenhouse dataran rendah di Wilayah Kota Depok, Jawa Barat.

\section{BAHAN DAN METODE}

Percobaan dilakukan dari bulan Oktober 2018 sampai dengan Januari 2019 di greenhouse Kampus F6 Universitas Gunadarma, Kota Depok, Jawa Barat. Greenhouse yang digunakan bertipe tropical greenhouse unit tunggal (detached houses) dengan konstruksi dinding berbahan screen-net (mesh 60\%) dan atap plastik UV. Ketinggian lokasi adalah $54 \mathrm{mdpl}$ dengan suhu harian rata-rata 27$29{ }^{\circ} \mathrm{C}$ serta kelembaban rata-rata 67-80\% (BMKG, 2019). Berdasarkan hasil pengukuran, suhu rata-rata di dalam greenhouse selama percobaan ini adalah $29-36{ }^{\circ} \mathrm{C}$.

Material genetik yang digunakan adalah lima varietas tomat hibrida komersial yaitu, varietas Tymoti, Tantyna, Rewako, Agatha, dan Ultima. Varietas Tymoti, Tantyna, dan Rewako dilepas sebagai varietas tomat sayur dengan tipe pertumbuhan determinate sedangkan varietas Agatha dan Ultima dilepas sebagai varietas tomat buah dengan tipe pertumbuhan indeterminate. Percobaan menggunakan rancangan lingkungan berupa rancangan kelompok lengkap teracak (RKLT) satu faktor dengan arah dari sistem irigasi tetes (drip irrigation) sebagai pengelompokannya. Faktor yang digunakan adalah varietas tomat. Setiap taraf diulang sebanyak tiga kali, sehingga terdapat 15 satuan percobaan. Setiap satuan percobaan terdiri atas delapan tanaman.

Bibit disemai selama 25 hari atau hingga berdaun 68 helai sebelum pindah tanam menggunakan media tanam campuran cocopeat dan arang sekam dengan perbandingan 1:1 (v/v). Penanaman menggunakan sistem hidroponik beririgasi tetes dengan media yang serupa dengan persemaian. Pemupukan menggunakan larutan $\mathrm{AB}$ mix dengan konsentrasi 500 ppm pada saat persemaian, 1,000 ppm saat fase vegetatif, dan ditingkatkan hingga 1,500 ppm saat fase generatif sebanyak $250 \mathrm{~mL}$ setiap hari per tanaman. Pemupukan lainnya adalah Gandasil D dan B sebanyak $2 \mathrm{~g}$ $\mathrm{L}^{-1}$ sebagai pupuk mikro tambahan pada fase vegetatif dan fase generatif yang diaplikasikan lewat daun. Pengukuran kekerasan buah menggunakan hand-penetrometer model GY-3 dan padatan terlarut total dengan digital-refractometer model MIMA871.

Pengamatan dilakukan pada seluruh tanaman dari setiap satuan percobaan. Karakter yang diamati terdiri atas karakter kualitatif dan kuantitatif mengikuti kunci karakterisasi IPGRI (1996). Karakter kualitatif yang diamati meliputi warna hipokotil, tipe pertumbuhan, warna ruas, letak daun, intensitas hijau daun, warna bunga, tipe tandan bunga, warna hijau di pundak buah muda, bentuk buah secara longitudinal, dan bentuk ujung buah pada fase generatif. Pengamatan pada karakter kuantitatif pada fase vegetatif yaitu, panjang daun, lebar daun, panjang tulang daun, dan diameter batang. Pengamatan terhadap karakter kuantitatif generatif yaitu, umur berbunga, umur panen, bobot per buah, panjang buah, diameter buah, tebal daging buah, jumlah buah, padatan terlarut total, dan kekerasan buah.

Data yang diperoleh diuji dengan uji kenormalan mengikuti metode kenormalan Kormogorov-Smirnov, sedangkan kehomogenan ragam menggunakan uji Bartlett untuk memenuhi asumsi sidik ragam $\operatorname{cij} \sim \operatorname{NID}\left(0, \sigma^{2}\right)$ dengan menggunakan perangkat lunak Minitab versi 16 . Setelah itu data dianalisis dengan analisis ragam atau uji $\mathrm{F}$ pada taraf nyata 5\%. Hasil uji F pada karakter yang nyata, dilanjutkan dengan uji kontras ortogonal untuk mengetahui perbedaan antara penampilan kelompok varietas determinate dengan kelompok varietas indeterminate. Selain itu dilakukan uji beda nyata jujur (BNJ) untuk mengetahui penampilan varietas terbaik menggunakan perangkat lunak SAS 9.1.

\section{HASIL DAN PEMBAHASAN}

\section{Karakter Kualitatif}

Hasil pengamatan karakter kualitatif fase vegetatif menunjukkan terdapat variasi dari kelima varietas tomat yang diuji yaitu, tipe tumbuh, letak daun, dan intensitas 
warna hijau daun (Tabel 1). Selain variasi pada fase vegetatif ditemukan pula variasi karakter kualitatif di fase generatif yaitu, tipe tandan bunga, warna hijau di pundak buah muda, bentuk buah, dan bentuk ujung buah (Tabel 2). Karakter kualitatif warna hipokotil, tipe pertumbuhan, intensitas hijau daun, warna hijau di pundak buah muda, dan bentuk buah sesuai dengan deskripsi pelepasan varietas dari masingmasing varietas uji. Menurut Reddy et al. (2017) karakter kualitatif umumnya dikendalikan oleh satu atau dua gen yang sederhana dan memiliki sifat sedikit dipengaruhi oleh lingkungan serta stabil di lingkungan tumbuh yang berbedabeda.

Semua varietas uji pada percobaan ini memiliki warna ungu pada karakter hipokotilnya. Warna hipokotil pada tomat hanya terdiri atas dua jenis warna yaitu, warna hijau dan ungu. Hipokotil warna ungu bersifat dominan terhadap hipokotil warna hijau (Kim et al., 2012; Mustafa et al., 2016). Penggunaan karakter hipokotil ungu umum digunakan pada varietas tomat hibrida. Karakter ini digunakan sebagai pengujian hibriditas tanaman tomat (Mustafa et al., 2016). Hal tersebut bermanfaat untuk mengetahui tingkat kemurnian benih (seed purity) yang digunakan oleh para urban farmer sebagai konsumen.

Varietas Tantyna, Tymoti, dan Rewako memiliki tipe pertumbuhan determinate sedangkan varietas Agatha dan Ultima memiliki tipe pertumbuhan indeterminate. Pertumbuhan determinate cenderung memiliki tinggi tanaman yang lebih pendek dibandingkan genotipe indeterminate (Sutjahjo et al., 2015; Chishti et al., 2019) dan memiliki keunggulan waktu berbunga yang lebih cepat dibandingkan indeterminate (Sujitno dan Dianawati, 2017). Karakteristik tipe tumbuh ini menjadi penting pada wilayah dataran rendah yang memiliki banyak faktor resiko untuk tanaman tomat seperti cekaman suhu panas, kekeringan, hingga serangan hama dan penyakit. Ganeva et al. (2018) melaporkan bahwa aksesi tomat indeterminate lebih rentan terhadap cekaman suhu tinggi dibandingkan aksesi tomat determinate.

Berdasarkan evaluasi terhadap varietas uji warna hijau dipundak buah (fruit greenback) dimiliki baik oleh varietas determinate dan indeterminate. Manurut Figas et al. (2018) warna hijau di pundak buah muda dikendalikan oleh gen sederhana. Reddy et al. (2017) menyatakan bahwa karakter pundak buah hijau dominan terhadap buah tanpa pundak buah dan stabil pada kondisi lingkungan yang berbeda. Oleh karena itu, karakter pundak buah hijau dapat pula digunakan untuk menguji hibriditas varietas hibrida pada pengujian tipe grow out (GOT) di fase generatif. Karakter warna pundak buah tidak identik dengan tipe pertumbuhan tanaman sebab terdapat di kedua kelompok varietas yang diuji.

Variasi bentuk buah lonjong dimiliki oleh varietas Agahta, Ultima, dan Tantyna. Selain itu, terdapat variasi bentuk ujung buah dari melekuk ke dalam hingga meruncing. Varietas dengan buah lonjong memiliki ujung buah mendatar hingga meruncing. Bentuk buah lonjong dengan ukuran sedang, memiliki rasa manis, keras dan berwarna kulit merah cerah menjadi preferensi kualitas bagi konsumen tomat (Irsyad et al., 2018). Menurut Reddy et al. (2017) karakter bentuk buah dan ujung buah dapat dijadikan sebagai karakter penciri pada tanaman tomat karena bersifat stabil.

\section{Karakter Kuantitatif}

Berdasarkan hasil uji kenormalan data dan kehomogenan ragam diketahui bahwa karakter-karakter pengamatan memenuhi kedua asumsi matematis sidik ragam tersebut atau salah satunya yaitu, data menyebar normal dan

Tabel 1. Karakter kualitatif fase vegetatif dari lima varietas tomat

\begin{tabular}{lclclc}
\hline Varietas & Warna hipokotil & Tipe Tumbuh & Warna 3 ruas atas & Letak daun & $\begin{array}{c}\text { Intensitas hijau } \\
\text { daun }\end{array}$ \\
\hline Aghata & Ungu & Indeterminate & Ungu & Menggantung & Hijau tua \\
Rewako & Ungu & Determinate & Hijau & Semi tegak & Hijau \\
Tantyna & Ungu & Determinate & Ungu & Horizontal & Hijau tua \\
Tymoti & Ungu & Determinate & Ungu & Horizontal & Hijau \\
Ultima & Ungu & Indeterminate & Ungu & Menggantung & Hijau \\
\hline
\end{tabular}

Tabel 2. Karakter kualitatif fase generatif dari lima varietas tomat

\begin{tabular}{|c|c|c|c|c|c|}
\hline Varietas & Warna bunga & Tipe tandan bunga & $\begin{array}{c}\text { Warna hijau di pundak } \\
\text { buah muda }\end{array}$ & Bentuk buah & $\begin{array}{l}\text { Bentuk ujung } \\
\text { buah }\end{array}$ \\
\hline Aghata & Kuning & Uniparous dan multiparous & Ada & Silinder & Datar meruncing \\
\hline Rewako & Kuning & Uniparous dan multiparous & Ada & Pipih & Melekuk \\
\hline Tantyna & Kuning & Uniparous & Ada & Bentuk hati & Meruncing \\
\hline Tymoti & Kuning & Uniparous & Tidak ada & Bulat & Melekuk \\
\hline Ultima & Kuning & Uniparous dan multiparous & Tidak ada & Telur sunggang & Meruncing \\
\hline
\end{tabular}


galat percobaan mempunyai keragaman yang sama (Tabel 3). Berdasarkan uji F (Fisher) pada taraf 5\% menunjukkan bahwa paling tidak terdapat satu varietas yang berbeda pada karakter yang diamati, yaitu panjang daun, lebar daun, panjang tulang daun, diameter batang, umur berbunga, bobot per buah, jumlah buah, panjang buah, diameter buah, tebal daging buah, padatan total terlarut, dan kekerasan buah.

Koefisien keragaman (KK) pada seluruh karakter uji berkisar antara 3.47-20.32\%, atau kurang dari 25\% (Tabel 4). Mejaya dan Moedjiono (1994) menyatakan bahwa koefisien keragaman kurang dari $25 \%$ masuk ke dalam kategori rendah pada pengujan tanaman jagung. Nilai koefisien keragaman lebih dari $30 \%$ seringkali mengindikasikan pengendalian percobaan di luar kontrol sehingga asumsi homogenitas ragam tidak terpenuhi (Gomez dan Gomez, 1984).

\section{Karakter Kuantitatif Fase Vegetatif}

Panjang daun rata-rata varietas tomat yang diuji berkisar antara 10.25-14.97 cm (Tabel 5). Kelompok tomat indeterminate memiliki rangkaian daun dengan panjang tulang daun lebih panjang dibandingkan tomat determinate.

Tabel 3. Uji kenormalan data dan kehomogenan ragam

\begin{tabular}{llcc}
\hline \multirow{2}{*}{ No } & \multicolumn{1}{c}{ Karakter } & \multicolumn{2}{c}{ Nilai peluang } \\
\cline { 3 - 4 } & & Kenormalan data & Kehomogenan ragam \\
\hline 1 & Panjang daun & 0.021 & 0.114 \\
2 & Lebar daun & $>0.150$ & 0.242 \\
3 & Panjang tulang daun & $>0.150$ & 0.155 \\
4 & Diameter batang & $>0.150$ & 0.775 \\
5 & Umur berbunga & $>0.150$ & 0.555 \\
6 & Umur panen & $>0.150$ & 0.337 \\
7 & Bobot per buah & 0.092 & 0.139 \\
8 & Panjang buah & $>0.150$ & 0.051 \\
9 & Diameter buah & $>0.150$ & 0.053 \\
10 & Tebal daging buah & $>0.150$ & 0.175 \\
11 & Jumlah buah & $>0.150$ & 0.317 \\
12 & Padatan terlarut total & $>0.150$ & 0.906 \\
13 & Kekerasan buah & 0.105 & 0.201 \\
\hline
\end{tabular}

Keterangan: Nilai $\mathrm{P}>0.05$ data menyebar nomal dan ragam homogen

Tabel 4. Rekapitulasi sidik ragam karakter hortikultura lima varietas tomat

\begin{tabular}{|c|c|c|c|}
\hline No & Karakter & Nilai F & $\% \mathrm{KK}$ \\
\hline 1 & Panjang daun $(\mathrm{cm})$ & $6.10^{*}$ & 11.13 \\
\hline 2 & Lebar daun $(\mathrm{cm})$ & $5.63^{*}$ & 7.74 \\
\hline 3 & Panjang tulang daun $(\mathrm{cm})$ & $18.76^{* *}$ & 7.03 \\
\hline 4 & Diameter batang $(\mathrm{cm})$ & $7.14 * *$ & 4.78 \\
\hline 5 & Umur berbunga (HST) & $25.89 * *$ & 9.66 \\
\hline 6 & Umur panen (HST) & $2.75 \mathrm{tn}$ & 7.50 \\
\hline 7 & Bobot per buah (g) & $74.19 * *$ & 7.23 \\
\hline 8 & Panjang buah (mm) & $57.03 * *$ & 6.06 \\
\hline 9 & Diameter buah (mm) & $11.18^{* *}$ & 4.40 \\
\hline 10 & Tebal daging uah (mm) & $15.30 * *$ & 7.38 \\
\hline 11 & Jumlah buah & $11.69 * *$ & 12.82 \\
\hline 12 & Padatan terlarut total $\left({ }^{\circ} \mathrm{Brix}\right)$ & $4.40 *$ & 7.01 \\
\hline 13 & Kekerasan buah $\left(\mathrm{kg} / \mathrm{cm}^{2}\right)$ & $25.54 * *$ & 20.32 \\
\hline
\end{tabular}

Keterangan: * = berpengaruh nyata pada taraf $5 \% ; * *=$ berpengaruh nyata pada taraf $1 \%$ berdasarkan uji $\mathrm{F}$; KK = koefisien keragaman 
Varietas tomat Agatha memiliki panjang daun terpanjang $(14.97 \mathrm{~cm})$ diantara keempat varietas lainnya. Perbedaan ini tidak signifikan bila dibandingkan dengan varietas Ultima yang juga merupakan kelompok varietas indeterminate.

Diameter batang rata-rata tomat yang diamati pada kisaran 9.20-11.23 cm. Kelompok tomat determinate memiliki diameter batang lebih kecil dibandingkan indeterminate. Ukuran diameter Tymoti terkecil dibandingkan tomat uji lainnya. Menurut Desita et al. (2015) karakter tinggi dikotomus, tinggi tanaman, dan diameter batang cabai menunjukkan hubungan berbanding lurus, di mana semakin tinggi tanaman cabai maka tinggi dikotomus dan diameter batang juga akan semakin besar.

\section{Karakter Kuantitatif Fase Generatif}

Terdapat perbedaan umur berbunga antara kelompok determinate dan indeterminate. Kelompok tomat determinate lebih cepat berbunga dibandingkan tomat indeterminate. Umur berbunga paling genjah ditunjukkan oleh varietas Rewako dengan waktu 15 hari setelah tanam lalu disusul oleh Tymoti (Tabel 6). Akan tetapi hal ini tidak sejalan dengan umur panen, dimana Tymoti relatif lebih awal panen dibandingkan varietas lainnya. Hal ini dapat dijelaskan bahwa kemampuan membentuk buah (fruit set) yang rendah akan berdampak pada umur panen tanaman. Tymoti memiliki fruit set yang lebih baik, ditandai dengan jumlah buah yang nyata lebih banyak dibandingkan Rewako (Tabel 6). Varietas Rewako mengalami gugur bunga yang sangat tinggi diantara varietas lainnya ditandai dengan jumlah buah yang sangat rendah. Menurut deskripsi varietas Rewako direkomendasikan untuk penanaman dataran rendah. Hal ini diduga varietas Rewako mengalami cekaman suhu tinggi (heat stress) di dalam greenhouse dataran rendah. Suhu tinggi menjadi salah satu efek dari budidaya di dalam greenhouse (Boulard et al., 2011).

Tabel 5. Nilai rata-rata karakter vegetatif lima varietas tomat

\begin{tabular}{lcccc}
\hline Varietas & $\begin{array}{c}\text { Panjang daun } \\
(\mathrm{cm})\end{array}$ & $\begin{array}{c}\text { Lebar daun } \\
(\mathrm{cm})\end{array}$ & $\begin{array}{c}\text { Panjang tulang daun } \\
(\mathrm{cm})\end{array}$ & $\begin{array}{c}\text { Diameter batang } \\
(\mathrm{cm})\end{array}$ \\
\hline Agatha (Ag) & $14.97 \mathrm{a}$ & $4.62 \mathrm{~b}$ & $41.83 \mathrm{a}$ & $10.44 \mathrm{ab}$ \\
Rewako (Re) & $10.25 \mathrm{~b}$ & $5.35 \mathrm{ab}$ & $27.89 \mathrm{c}$ & $10.36 \mathrm{ab}$ \\
Tantyna (Ta) & $11.07 \mathrm{~b}$ & $6.08 \mathrm{a}$ & $32.82 \mathrm{bc}$ & $10.87 \mathrm{a}$ \\
Tymoti (Ty) & $10.81 \mathrm{~b}$ & $5.50 \mathrm{ab}$ & $28.90 \mathrm{c}$ & $9.20 \mathrm{~b}$ \\
Ultima (Ul) & $11.71 \mathrm{ab}$ & $5.97 \mathrm{a}$ & $38.00 \mathrm{ab}$ & $11.23 \mathrm{a}$ \\
\hline Determinate vs Indeterminate & $* *$ & tn & $* *$ & $*$ \\
Ag vs Ul & $*$ & $* *$ & tn & tn \\
Ta vs Ty \& Re & th & $*$ & tn & $* *$ \\
Ty vs Re & tn & tn & $*$ \\
\hline
\end{tabular}

Keterangan: Angka-angka yang diikuti huruf yang sama pada kolom yang sama menunjukkan tidak berbeda nyata pada uji lanjut BNJ taraf $5 \%$ dan $*$ = berbeda nyata pada taraf nyata $5 \% ; * *=$ berbeda nyata pada taraf $1 \%$; th $=$ tidak berbeda nyata berdasarkan uji kontras ortogonal

Tabel 6. Nilai rata-rata karakter generatif lima varietas tomat

\begin{tabular}{lcccc}
\hline Varietas & $\begin{array}{c}\text { Umur berbunga } \\
(\mathrm{HST})\end{array}$ & $\begin{array}{c}\text { Umur panen } \\
(\mathrm{HST})\end{array}$ & $\begin{array}{c}\text { Bobot per buah } \\
(\mathrm{g})\end{array}$ & $\begin{array}{c}\text { Jumlah buah per } \\
\text { tanaman }\end{array}$ \\
\hline Agatha (Ag) & $21.00 \mathrm{~b}$ & 83.79 & $86.47 \mathrm{a}$ & $11.00 \mathrm{bc}$ \\
Rewako (Re) & $15.33 \mathrm{~b}$ & 78.00 & $40.57 \mathrm{~cd}$ & $3.66 \mathrm{c}$ \\
Tantyna (Ta) & $28.38 \mathrm{a}$ & 72.80 & $50.77 \mathrm{c}$ & $25.33 \mathrm{a}$ \\
Tymoti (Ty) & $20.88 \mathrm{~b}$ & 69.75 & $37.93 \mathrm{~d}$ & $24.00 \mathrm{ab}$ \\
Ultima (Ul) & $32.17 \mathrm{a}$ & 73.80 & $68.22 \mathrm{~b}$ & $13.67 \mathrm{abc}$ \\
\hline Determinate vs Indeterminate & $*$ & tn & $* *$ & tn \\
Ag vs Ul & $* *$ & tn & $* *$ & tn \\
Ta vs Ty \& Re & $* *$ & tn & tn & $*$ \\
Ty vs Re & tn & tn & & $* *$ \\
\hline
\end{tabular}

Keterangan: Angka-angka yang diikuti huruf yang sama pada kolom yang sama menunjukkan tidak berbeda nyata pada uji lanjut BNJ taraf $5 \%$ dan $*$ = berbeda nyata pada taraf nyata $5 \% ; * *=$ berbeda nyata pada taraf $1 \%$; tn = tidak berbeda nyata berdasarkan uji kontras ortogonal 
Suhu rata-rata di dalam greenhouse selama penelitian lebih tinggi $2-5{ }^{\circ} \mathrm{C}$ dibandingan suhu di luar. Suhu udara yang relatif tinggi serta kelembaban yang relatif rendah di dalam greenhouse menyebabkan bunga tomat mudah gugur (Kusumayati et al., 2015). Karakter pembungaan besar dipengaruhi oleh kondisi lingkungan (Hermanto et al., 2017; Figas et al., 2018). Kemampuan fruit set akan menurun secara signifikan dengan meningkatnya suhu harian (Chrishti et al., 2019). Di dalam kondisi optimal, karakter umur berbunga berbanding lurus dengan bobot buah (Desita et al., 2015).

Varietas indeterminate nyata memiliki ukuran buah lebih besar dibandingkan varietas determinate. Ukuran buah varietas Agatha dan Ultima sesuai untuk permintaan pasar tomat buah sedangkan varietas Tymoti, Tantyna, dan Rewako untuk memenuhi pasar tomat sayur. Tymoti merupakan tomat sayur dengan ukuran buah kecil sedangkan Tantyna memiliki ukuran buah sedang (Daryanto dan Yulianti, 2019). Tomat buah pada umumnya memiliki ukuran buah lebih besar dibandingkan tomat sayur dan rasa tomat sayur akan lebih segar dibandingkan tomat buah (Hermanto et al., 2017). Tomat buah dengan ukuran besar diperjualbelikan di pasar-pasar modern sedangkan tomat buah ukuran kecil dan sedang banyak diperjualbelikan di pasar-pasar tradisional atau pedagang sayur (Irsyad et al., 2018).

Varietas Agatha memiliki dimensi buah (panjang buah, diameter buah dan tebal daging buah) signifikan lebih besar diantara varietas lainnya (Tabel 7). Selain itu varietas Agatha memiliki bobot buah terbesar diantara varietas uji lainnya yaitu, $86.47 \mathrm{~g}$ lalu disusul oleh varietas Ultima $68.22 \mathrm{~g}$ (Tabel 6). Penanaman tomat varietas Agatha dan
Ultima di dataran rendah masih dapat dilakukan akan tetapi dapat menurunkan potensi hasil dan dimensi ukuran buah. Bobot buah varietas Agatha mengalami penurunan sebesar $40 \%$ bila dibandingkan dengan data yang tercantum di dalam pelepasan varietas Kementerian Pertanian Indonesia (Dirjen Perbenihan Hortikultura, 2020). Ganeva et al. (2018) melaporkan bahwa di dalam kondisi cekaman suhu tinggi tomat indeterminate dapat tereduksi produksinya hingga $76 \%$.

Karakter bobot buah merupakan karakter kuantitatif yang dipengaruhi oleh faktor lingkungan. Penanaman pada areal dengan agroklimat yang berbeda akan berdampak besar pada karakter hasil seperti ukuran buah (Ganeva et al., 2018). Wilayah adaptasi yang direkomendasikan untuk varietas Agatha dan Ultima adalah dataran tinggi dengan ketinggian 1,000-1,300 mdpl sedangkan varietas Tymoti, Tantyna, dan Rewako direkomendasikan di dataran rendah sampai medium dengan ketinggian 75-585 mdpl (Ditjen Perbenihan Hortikultura, 2020). Oleh karena itu varietas Agatha dan Ultima tidak dapat mengekspresikan potensi genetiknya secara sempurna di wilayah Depok, daerah dataran rendah.

Karakter penting lainnya adalah kekerasan buah. Kekerasan buah menjadi salah satu preferensi tomat terutama untuk ketahanan terhadap kerusakan fisik selama transportasi (Lospiani et al., 2017). Kekerasan buah merupakan karakter yang stabil baik dalam kondisi naungan atau kondisi cahaya penuh (Baharuddin et al., 2014). Varietas Ultima memiliki kualitas kekerasan buah, tebal kulit buah, dan padatan terlarut total nyata lebih tinggi dibandingkan varietas lainnya.

Tabel 7. Nilai rata-rata karakter komponen hasil lima varietas tomat

\begin{tabular}{|c|c|c|c|c|c|}
\hline Genotipe & $\begin{array}{l}\text { Panjang buah } \\
(\mathrm{mm})\end{array}$ & $\begin{array}{l}\text { Diameter buah } \\
(\mathrm{mm})\end{array}$ & $\begin{array}{l}\text { Tebal daging } \\
\text { buah }(\mathrm{mm})\end{array}$ & $\begin{array}{c}\text { PTT } \\
\text { ( }{ }^{\circ} \text { Brix) }\end{array}$ & $\begin{array}{c}\text { Kekerasan buah } \\
\left(\mathrm{kg} \mathrm{cm}^{-2}\right)\end{array}$ \\
\hline Agatha (Ag) & $61.84 \mathrm{a}$ & $49.70 \mathrm{a}$ & $6.80 \mathrm{a}$ & $5.06 a b$ & $2.71 b$ \\
\hline Rewako (Re) & $28.70 \mathrm{~d}$ & $44.93 \mathrm{ab}$ & $4.53 c$ & $4.47 \mathrm{ab}$ & $1.93 b$ \\
\hline Tantyna (Ta) & $49.00 \mathrm{bc}$ & $43.93 \mathrm{bc}$ & $6.62 \mathrm{a}$ & $4.90 \mathrm{ab}$ & $3.79 b$ \\
\hline Tymoti (Ty) & $41.41 \mathrm{c}$ & $39.16 \mathrm{c}$ & $5.30 \mathrm{bc}$ & $4.35 b$ & $2.06 \mathrm{~b}$ \\
\hline Ultima (U1) & $49.67 b$ & $45.87 \mathrm{ab}$ & $6.54 \mathrm{ab}$ & $5.33 \mathrm{a}$ & $6.94 \mathrm{a}$ \\
\hline Determinate vs Indeterminate & $* *$ & $* *$ & $* *$ & $* *$ & $* *$ \\
\hline Ag vs Ul & $* *$ & $*$ & tn & tn & $* *$ \\
\hline Ta vs Ty \& Re & $* *$ & $\operatorname{tn}$ & $* *$ & $\operatorname{tn}$ & $* *$ \\
\hline Ty vs Re & $* *$ & $* *$ & th & tn & tn \\
\hline
\end{tabular}

Keterangan: Angka-angka yang diikuti huruf yang sama pada kolom yang sama menunjukkan tidak berbeda nyata pada uji lanjut BNJ taraf $5 \%$ dan $*$ = berbeda nyata pada taraf nyata $5 \% ; * *$ = berbeda nyata pada taraf $1 \%$; th = tidak berbeda nyata berdasarkan uji kontras ortogonal

\section{KESIMPULAN}

Lima varietas yang diuji memiliki perbedaan pada semua karakter kuantitatif yang diamati meliputi karakter vegetatif (panjang daun, lebar daun, dan diameter batang) dan generatif (umur berbunga, bobot per buah, jumlah buah, panjang buah, diameter buah, tebal daging buah, total padatan terlarut, dan kekerasan buah). Karakter kualitatif yang mencirikan varietas adalah tipe tumbuh, warna pundak buah muda, bentuk buah, dan bentuk ujung buah. Penanaman 
tomat varietas indeterminate, Agatha dan Ultima, di dataran rendah masih dapat dilakukan akan tetapi dapat menurunkan potensi dimensi ukuran buah. Varietas Tymoti dan Tantyna dapat tumbuh dan berkembang dengan baik pada kondisi penanaman di dalam greenhouse dataran rendah sedangkan varietas Rewako dengan tipe pertumbuhan determinate yang sama mengalami kerontokan bunga yang tinggi dan penurunan potensi hasil.

\section{DAFTAR PUSTAKA}

Ashari, Saptana, T.B. Purwantini. 2012. Potensi dan prospek pemandaatan lahan pekarangan untuk mengukung ketahanan pangan. Forum Penelitian Agro Ekonomi. 30:13-30.

[BMKG] Badan Meteorologi, Klimatologi, dan Geofisika. 2019. Data Online Stasiun Halim Perdana Kusuma Jakarta. http://dataonline.bmkg.go.id/home [1 September 2019].

Baharuddin, R., M.A. Chozin, M. Syukur. 2014. Toleransi 20 genotipe tanaman tomat terhadap naungan. J. Agron. Indonesia 42:130-135.

Bojaca, C.R., K.A.G. Wyckhyus, E. Schrevens. 2014. Life cycle assessment of Colombian greenhouse tomato production based on farmer-level survey data. J. Cleaner Prod. 69:26-33.

Boulard, T., C. Raeppel, R. Brun, F. Lecompte, F. Hayer, G. Carmassi, G. Gaillard. 2011. Environmental impact of greenhouse tomato production in France. Agron. Sust. Dev. 31:757-777.

Carrillo-Rodríguez, J.C., J.L. Chavez-Servia, R. LobatoOrtiz, C. Perales-Segovia. 2019. Generation and evaluation of heterogeneous genotypes of tomato for small-scale farmers. J. Plant Breed. Crop Sci. 11:9199.

Chishti, S.A.S., M.M. Hussain, I. Ali, K. Nadeem, A. Saeed, S. Jalil. 2019. Temperature based crop modeling for round the year tomato production in Pakistan. J. Agric. Res. 57:25-32.

Daryanto, A., F. Yulianti. 2019. Efektivitas beberapa metode ekstraksi terhadap mutu benih dua varietas tomat determinate (Solanum lycopersicum L). J. Pertanian Presisi 3:14-24.

Direktorat Perbenihan Hortikultura. 2020. Database Varietas Tomat. http://varitas.net/dbvarietas/. [12 April 2020].

Desita, A.Y., D. Sukma, M. Syukur. 2015. Evaluasi karakter hortikultura galur cabai hias IPB di kebun percobaan Leuwikopo. J. Hort. Indonesia 6:116-123.
Figas, M.R., J. Prohens, C. Casanova, P. Fernandezde-Cordova. 2018. Variation of morphological descriptors for the evaluation of tomato germplasm and their stability across different growing conditions. Sci. Hort. 238:107-115.

Ganeva, D.G., Y. Stanislava, Grozeva, T. Galina, Pevicharova. 2018. Evaluation of production and productivity compounds in tomato accessions grown under elevated temperature and reduced irrigation. J. Inter. Sci. Pub. 6:99-110.

Geethanjali, S., K.Y. Chen, D.V. Pastrana, J.F. Wang. 2010. Development and characterization of tomato SSR markers from genomic sequences of anchored BAC clones on chromosome 6. Euphytica.173:85-97.

Gomez, K.A., A.A. Gomez. 1984. Statistical Procedures for Agricultural Research. 2nd Edition. John Wiley \& Sons. New York.

Guan, Z., T. Biswas, F. Wu. 2018. The US Tomato Industry: An overview of production and trade. EDIS. The Food and Resource Economics Department, UF/IFA.

Hermanto, R., M. Syukur, Widodo. 2017. Pendugaan ragam genetik dan heritabilitas karakter hasil dan komponen hasil tomat (Lycopersicum esculentum Mill) di dua lokasi. J. Hort. Indonesia 8:31-38.

IPGRI, 1996. Descriptors for Tomato (Lycopersicon Spp.). International Plant Genetic Resources Institute, Rome, IT.

Irsyad, E.P., A.Yoesdiarti, H. Miftah. 2018. Analisis persepsi dan preferensi konsumen terhadap atribut kualitas sayuran komersial di pasar modern. J. Agribisains $4: 1-7$.

Lospiani, N.P.N., I.M.S. Utama, I.A.R.P. Pudja. 2017. Pengaruh lama waktu cekaman anaerobic dan konsentrasi emulsi lilin lebih sebagai bahan pelapis terhadap mutu dan masa simpan buah tomat. J. Beta 5:9-19.

Kim, H.J., H.R. Lee, J.Y. Hyun, D.C. Won, D.O. Hong, C.H. Harn. 2012. CAPS marker linked to tomato hypocotyl pigmentation. Kor. J. Hort. Sci. Technol. 30: 56-63.

Kusumayati, N., E.E. Nurlaelih, L. Setyobudi. 2015. Tingkat keberhasilan pembentukan buah tiga varietas tanaman tomat (Lycopersicon esculentum Mill.). J. Prod. Tan. 3:683-688.

Mejaya, M.J., Moedjiono. 1994. Variabilitas genetik beberapa karakter plasma nutfah jagung koleksi Balittan Malang. Zuriat 3:27-32. 
Mustafa, M., M. Syukur, S.H. Sutjahjo, Sobir. 2016. Pewarisan karakter kualitatif dan kuantitatif pada hipokotil dan kotiledon tomat (Solanum lycopersicum L.) silangan IPB T64 x IPB T3. J. Hort. Indonesia $7: 155-164$

Priya, V.V., K.R. Saravanan, M. Prakash, R. Anandan. 2019. Assessment of molecular diversity in tomato genotypes using RAPD and SSR markers. Plant Archives 19:3437-3445.

[Pusdatin] Pusat Data dan Sistem Informasi Pertanian. 2017. Outlook komoditi tanaman pangan dan hortikultura. http:/epublikasi.setjen.pertanian.go.id/epublikasi/ outlook/2017/Outlook\%20TPHO RTI\%2017/files/ assets/basichtml/page114.html. [10 Juni 2019].

Reddy, K.K.C., S.K. Jain, A. Kumar, G. Krishnan, A.K. Singh, Z. Hussain. 2017. Morphological markers for identification of hybrids and their parental lines in tomato (Solanum lycopersicum L.). Indian J. Agri. Sci. 87:694-699.

Shamshiri, R.R., J.W. Jones, K.R. Thorp, D. Ahmad, H.C.Man, S. Taheri. 2018. Review of optimum temperature, humidity, and vapour pressure deficit for microclimate evaluation and control in greenhouse cultivation of tomato: a review. Int. Agrophys. 32:287-302.

Shivaprasad, P.V., R.M. Dunn, B.A.C.M. Santos, A. Bassett, D.C. Baulcombe. 2012. Extraordinary transgressive phenotypes of hybrid tomato are influenced by epigenetics and small silencing RNAs. EMBO J. 31:257-266.

Sujitno, E., M. Dianawati. 2017. Respon berbegai varietas terhadap produksi tomat di lahan kering dataran tinggi kabupaten Garut, Jawa Barat. Bul. Hasil Kajian 7:6266.

Sutjahjo, S.H., C. Herison, I. Sulastrini, S. Marwiyah. 2015. Pendugaan keragaman genetik beberapa karakter pertumbuhan dan hasil pada 30 genotipe tomat lokal. J. Hort. 25:304-310.

Yuan, X.K., Z.Q. Yang, Y.X. Li, Q. Liu, W. Han. 2016. Effect of different levels of water stress on leaf photosynthetic characteristics and antioxidant enzyme activities of greenhouse tomato. Photosynthetica. 54:28-39. 